\title{
Targeting Cancer Immunotherapy through Vaccination Using Irradiated Xenogeneic Placental Extract
}

\author{
Soheir A. A. Osman, Nadia M. Abdallah*, Fatma F. Abdel Hamid*, Mohamed H. \\ Nasr el-Dien**, Asmaa Abu Bakr and Dalia M. Mostafa ${ }^{\#}$ \\ Radiation Biology Department, National Center for Radiation Research and \\ Technology (NCRRT), Atomic Energy Authority (AEA); *Biochemistry Department, \\ Faculty of Science, Ain Shams University and **Faculty of Medicine, Ain Shams \\ University, Cairo, Egypt.
}

$\mathbf{T}$

HIS STUDY investigates the injection of sterilized xenogeneic placental protein extract before challenge with viable Ehrlich tumor cells for enhancement of the immune system. It includes the estimation of tumor size, hematological study and determination of CD8, granzyme B enzyme and caspase-3 activities, MMP-(2\&9) activities and protein fractionation in serum.

Female mice are divided into: G1 is the control group. G2 is the Ehrlich treated group, injected with $2.5 \times 105$ viable tumor cells/mouse. G3 is vaccinated with xenogeneic placental extract (XPE) sterilized using 0.2 micron Millipore filters. G4 is vaccinated with XPE sterilized with gamma irradiation at dose level of 2 Gy. G3 and G4 are subdivided into a, b, c and d.

Results demonstrated that subgroups 3a, 3c, 3d, 4a, 4b, 4c and 4d showed significant decrease in mean tumor size compared to G2. For lymphocyte count, subgroups $3 \mathrm{~d}, 4 \mathrm{~b}, 4 \mathrm{c}$ and $4 \mathrm{~d}$ revealed a significant increase compared to G1. Subgroup $4 \mathrm{~d}$ showed a significant increase in both CD8 and granzyme B activities compared to G1. The caspase- 3 activity indicated significantly in subgroups $4 \mathrm{c}$ and $4 \mathrm{~d}$ compared to G1. Serum MMP-(2\&9) activities revealed that the $4 \mathrm{~d}$ subgroup displays the less pronounced band compared to the other groups and to $\mathrm{G} 2$. Gel electrophoresis showed that Ehrlich protein and placental protein extract were represented by four bands detected at $7 \mathrm{kDa}$, between $29 \mathrm{kDa}$ and $45 \mathrm{kDa}$, at $>67 \mathrm{kDa}$ and at $>116 \mathrm{kDa}$.

It could be concluded that vaccination using xenogeneic placental extract targets the stimulation of the immune system.

Keywords: Immunotherapy, xenogeneic placental extract (XPE), cytotoxic T lymphocyte, granzyme B, Caspase- 3 .

\section{Introduction}

Cancer is a leading cause of death all over the world, and the number of cases globally continues to increase (Jemal et al., 2011). Most cancers can be prevented or cured if detected at an early stage and treated. Unfortunately, due to the lack of ideal cancer biomarkers for early detection and diagnosis, most patients present with advancedstage disease at the time of diagnosis, which limits the potential for successful treatment (Wagner \& Srivastava, 2012).
Tumorigenesis is a multistep process in which a succession of genetic alterations, conferring some proliferative advantages, causes progressive conversion of normal cells into cancer cells (Voron et al., 2014). The genetic alterations include sustaining proliferative signaling, evading growth suppressors, resisting cell death, enabling replicative immortality, activating invasion, metastasis, inducing angiogenesis, deregulating cellular energetics and avoiding immune destruction (Hanahan \& Weinberg, 2011).

The metastatic process involves intravasation

\#Correspondsing author email: daliabadreldeen@outlook.com

DOI: 10.21608/ejrsa.2018.2694.1039

C2018 The National Information and Documentation Center (NIDOC) 
and extravasation of tumor cells, followed by reimplantation of tumor cells, development of a new tumor stroma, and neoangiogenesis to consolidate a secondary tumor at a distant site (Hanahan \& Weinberg, 2000). Thus, matrix metalloproteinases (MMP) are central to tissue invasion by cancer cells, as tumors expand and form metastases (Xu et al., 2005).

Common cancer treatments including chemotherapy and radiotherapy often cause considerable side effects therefore cancer immunotherapy has emerged as a promising approach for cancer treatment (Kochenderfer \& Rosenberg, 2013).

Immunotherapy of cancer takes place through cytotoxic T lymphocytes (CTLs) and natural killer (NK) cells which work via two main pathways. First CTLs expressing ligands of the tumor necrosis factor superfamily on their cell surface can kill target cells expressing the corresponding receptors, whereas NK cells depend mainly on the granule-dependent pathway, which is the second cell death pathway involving the pore-forming protein perforin which allows the delivery of granzymes to the target cell, promoting the activation of the family of death-inducing proteases (caspases) (Cullen \& Martin, 2008).

Vaccines are synthesized to prepare the immune system to encounter cancer, when certain common challenges need to be faced, such as what antigen and what adjuvant to use, what type of immune response to generate and how to make it long lasting. Cancer vaccines must defeat immune suppression produced by the tumor and also must elicit effective long-term memory without the potential of causing autoimmunity (Finn, 2003).

The homology between neoplastic tissue and the developed placenta can be used to develop an approach for eliciting antitumor immunity (Zhong et al., 2006). Many proliferative, invasive and immune tolerance mechanisms that maintain normal human pregnancy are also exploited by malignancies to create a nutrient supply and evade or edit the host immune response. Beside the shared capacity for invading through normal tissues, both cancer cells and cells of the developed placenta create a microenvironment supportive of both immunologic privilege and angiogenesis (Holtan et al., 2009).
This study aims to investigate the efficiency of cancer immunotherapy by injection of xenogeneic placental protein extract as a vaccine before tumor formation to detect its selective cytotoxicity toward tumor cells by enabling the animal's immune system to respond against the cancer and in turn control or eliminate the cancer.

\section{Materials and Methods}

\section{Experimental animals}

Female Swiss albino mice weighing 22$25 \mathrm{~g}$ were used. Animals were obtained from the animal farm of the Egyptian Holding Company for Biological Products and Vaccines; Cairo, Egypt.

\section{Cell line}

Ehrlich ascites tumor cell line was kindly gifted from the National Cancer Institute, Cairo University.

\section{Radiation source}

Irradiation process was performed using ${ }^{137} \mathrm{Cs}$ irradiation unit, model Gamma cell-40 at the National Centre for Radiation Research and Technology (NCRRT), Atomic Energy Authority, Cairo, Egypt.

Preparation of the xenogeneic placental protein extract

Normal human placenta tissue from full term delivery was obtained from delivering woman in El-Demerdash hospital, placed on ice for transportation.

The placenta was washed in sterile phosphate buffered saline (PBS) containing 5\% penicillin streptomycin mixture. Vascularized placental tissue was freshly homogenized with tissue grinder and exposed to 4 freeze-thaw cycles alternating from liquid nitrogen to $42^{\circ} \mathrm{C}$ water bath. Cell debris was pelleted by centrifugation at $1500 \mathrm{~g}$ for 45 min and supernatant was collected.

\section{Sterilization of the xenogeneic placental protein extract}

A part of the placental extract was sterilized using 0.2 micron Millipore filters (Centricon) in order to obtain a fraction having molecular weight less than $3 \mathrm{KDa}$ (Lee \& Hsu, 2004). The other part of the placental extract was sterilized using a minimum dose of gamma radiation (2 Gy) which is necessary for sterilization without causing placental protein degradation (Harrell, 1991). 


\section{Choice of protein concentration}

The sterilized placental protein preparation dissolved into sterile PBS at a concentration 2, 4 and $6 \mathrm{mg} / \mathrm{ml}$, respectively. Each concentration was injected in 10 mice subcutaneously at volume $100 \mu 1 /$ mouse in the right thigh 7 days before being sacrificed. Then, spleen samples from the three groups were collected. $0.5 \mathrm{mg}$ spleen were dissected in 10ml media (100 ml of RPMI-1640 medium, $10 \mathrm{ml}$ of fetal calf serum and $1 \mathrm{ml}$ of antibiotic \{streptomysin sulphate equivalent to $1 \mathrm{gm}$ streptomysin base\}) for releasing spleenocytic cells, filtered by mish and used as effector cells for MTT assay. The results obtained indicated that $6 \mathrm{mg} / \mathrm{ml}$ protein conc. was the best protein conc to be used in this study.

\section{Animal groups}

In this study, 255 mice were divided into four main groups. First group (G1): is the untreated group (control group) (15 mice). Second group (G2): is the Ehrlich treated group (contains 120 mouse divided into eight subgroups, injected with $2.5 \times 10^{5}$ viable Ehrlich tumor cells/mouse at the same time of challenge of each subgroup of G3 or $\mathrm{G} 4$ and then sacrificed at the same time of each subgroup.

Third group (G3) is vaccinated with $6 \mathrm{mg} /$ $\mathrm{ml}$ xenogeneic placental extract sterilized using 0.2 micron Millipore filters. Fourth group (G4) is vaccinated with $6 \mathrm{mg} / \mathrm{ml}$ xenogeneic placental extract sterilized using gamma irradiation at a dose rate of $2 \mathrm{~Gy}$.

Each of the third and fourth group contains 60 mice and divided into 4 subgroups (a, b, c and d) each contains 15 mice.

Groups 3a and 4a immunized once with $6 \mathrm{mg} /$ $\mathrm{ml}$ sterilized placental extract and challenged after one week with $2.5 \times 10^{5}$ viable Ehrlich tumor cells/ mouse. Groups $3 \mathrm{~b}$ and $4 \mathrm{~b}$ immunized three times with one week interval using $6 \mathrm{mg} / \mathrm{ml}$ sterilized placental extract. Groups $3 \mathrm{c}$ and $4 \mathrm{c}$ immunized once with $6 \mathrm{mg} / \mathrm{ml}$ sterilized placental extract and challenged after four weeks with $2.5 \times 10^{5}$ viable Ehrlich tumor cells/mouse. Groups $3 \mathrm{~d}$ and $4 \mathrm{~d}$ immunized three times with four week interval using $6 \mathrm{mg} / \mathrm{ml}$ sterilized placental extract.

\section{Sampling}

Blood samples were collected from heart and drained in 2 tubes; one is EDTA containing ependorff for haematological study and the other tube for serum separation for caspase 3, CD8, granzyme $\mathrm{B}$, metalloproteases tests and protein fractionation pattern.

\section{Methods}

1)3-(4,5-dimethylthiazole-2-yl)-2,5-dipheny ltetrazolium bromide (MTT) viability assay was carried out according to Wilson et al. (1990) with some modifications.

2) Measurement of tumor size using caliper, which was documented 3 times a week by applying the equation described by Nagle et al. (2004).

3) Lymphocyte count was performed using the blood counter 2800 mindray.

4) The activities of $\mathrm{CD} 8$, granzyme $\mathrm{B}(\mathrm{Gr} \mathrm{B})$ and caspase-3 were detected in serum using mouse (CD8, Gr B or Caspase-3) ELISA kit which is a product of WKEA MED SUPPLIES Company, China according to Karen et al. (2014).

5) Serum matrix metalloproteinases (MMPs) was determined using polyacrylamide gel electrophoresis according to Birkedal-Hansen \& Taylor (1982).

6) Fractionation of placental, Ehrlich and serum samples protein were carried out using polyacrylamide gel electrophoresis. Protein fractionation was quantitatively assessed by vertical slap SDS-PAGE according to Wittig et al. (2006).

\section{Statistical analysis}

Statistical analysis was performed using Duncan's multiple range test in SAS "Statistical Analysis System", 1988.

\section{$\underline{\text { Results }}$}

MTT viability assay

Table 1 shows that The G3 group revealed a significant increase in percentage of apoptosis compared to the normal group.

\section{Tumor size}

Figure 1 shows that the studied subgroups (3a, 3c, 3d, 4a, 4b, 4c and 4d) showed significant decreases in mean tumor size each compared to Ehrlich treated group (G2). 
TABLE 1. Apoptosis percentage of Ehrlich tumor cells by spleenocytic cells of mice injected with $2 \mathrm{mg}, 4 \mathrm{mg}$ and $6 \mathrm{mg}$ protein concentration.

\begin{tabular}{lcccc}
\hline Groups & N & GA & GB & GC \\
\hline Mean viability \pm S.D. & $58 \pm 2.9$ & $53 \pm 4.04$ & $48 \pm 13.6$ & $32 \pm 2.5$ \\
\% Apoptosis & 42 & 47 & 52 & 68 \\
\% Change & --- & 11.9 & 23.8 & 62 \\
P1 & --- & N.S. & N.S. & 0.01 \\
P2 & N.S. & --- & N.S. & 0.01 \\
P3 & N.S. & N.S. & ---05 \\
P4 & 0.01 & 0.01 & 0.05 & --- \\
\hline
\end{tabular}

$\mathrm{N}$ : Untreated group of mice.

GA: Group of mice injected with $2 \mathrm{mg}$ placental extract.

GB: Group of mice injected with $4 \mathrm{mg}$ placental extract.

GC: Group of mice injected with $6 \mathrm{mg}$ placental extract.

$(\mathbf{p}<\mathbf{0 . 0 1})$ : High significant.

$(\mathbf{p}<\mathbf{0 . 0 5})$ : Significant.

p1: $\mathrm{p}<$ vs. N. p2: $\mathrm{p}<$ vs. GA. p3: $\mathrm{p}<$ vs. GB. p4: $\mathrm{p}<$ vs. GC.

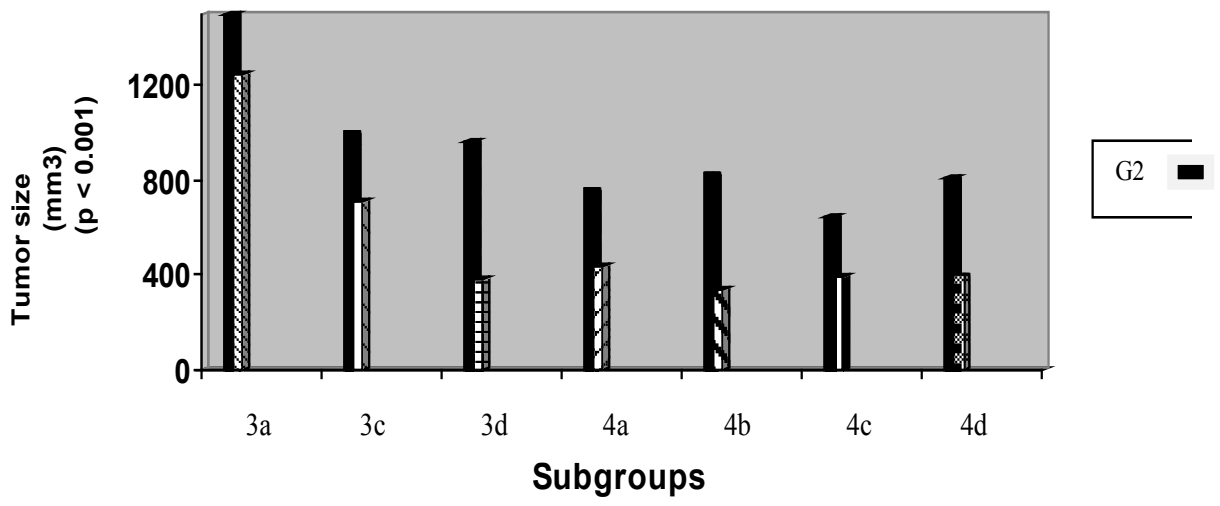

Fig. 1. A significant decrease in tumor size $\left(\mathrm{mm}^{3}\right)(\mathrm{p}<0.001)$ in mice vaccinated with XPE, 10 days after appearance of tumor compared to Ehrlich G2 group.

\section{Lymphocyte count}

Figure 2 demonstrates that the $3 d, 4 b, 4 c$ and $4 \mathrm{~d}$ subgroups showed significant increases in percentage of change of lymphocyte count compared to $\mathrm{G} 1$. In addition, $3 \mathrm{~d}, 4 \mathrm{a}, 4 \mathrm{~b}, 4 \mathrm{c}$ and $4 \mathrm{~d}$ subgroups showed significant increases in the percentage of change compared to Ehrlich treated (G2) group.

\section{CD8 activity in serum}

Figure 3 shows that $4 \mathrm{~d}$ subgroup showed a significant increase in CD8 activity compared to the $\mathrm{G} 1$, while $4 \mathrm{~b}$ and $4 \mathrm{~d}$ subgroups showed significant increases compared to Ehrlich treated group (G2).

Granzyme B activity in serum

Figure 4 reveals that $4 \mathrm{~d}$ subgroup showed a significant increase in granzyme B activity compared to G1 and G2.

\section{Caspase-3 activity in serum}

Figure 5 shows the significant increase in caspase- 3 activity for $4 \mathrm{c}$ and $4 \mathrm{~d}$ subgroups compared to the G1 and G2 groups.

\section{Serum MMP-(2\&9) activities}

Figure 6 shows the serum gelatin zymography for MMP-(2\&9) activity for all the studied groups compared to G1 and G2 groups, $4 \mathrm{~d}$ subgroup displayed the less pronounced band compared to the other studied subgroups and to Ehrlich treated group (G2). 


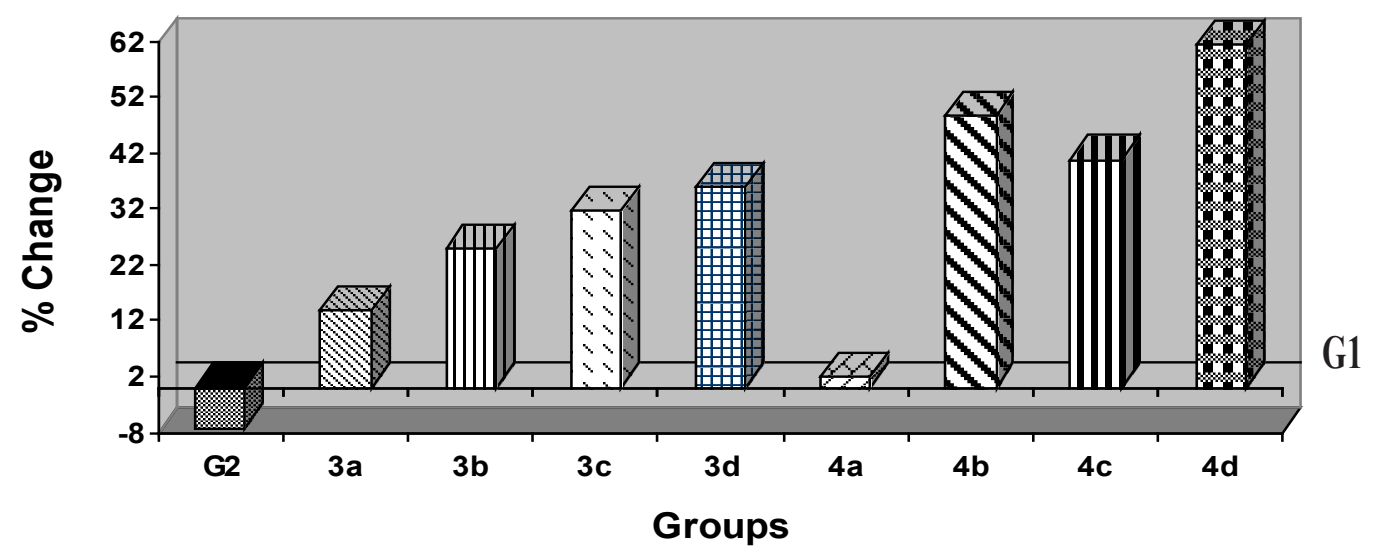

Fig.2. Change percentage of lymphocyte count (cell/ml) in blood of all the studied groups.

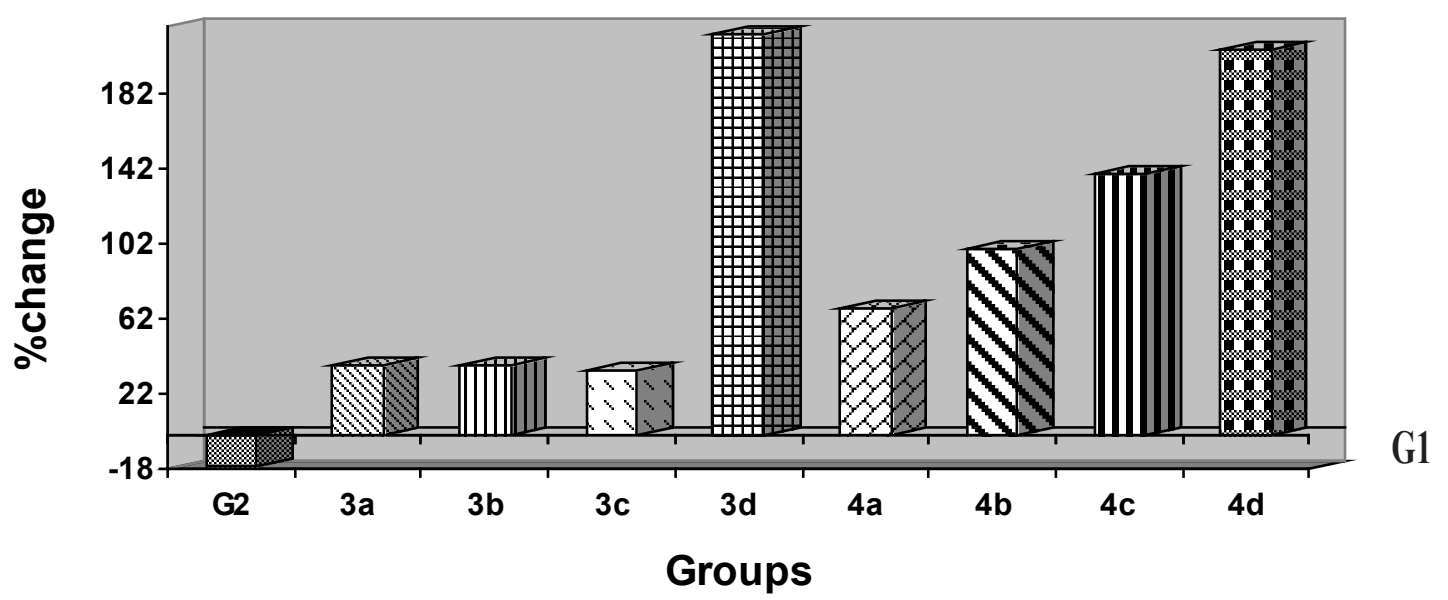

Fig. 3. Change percentage of CD8 activity $(\mathrm{U} / \mathrm{ml})$ of all studied groups.

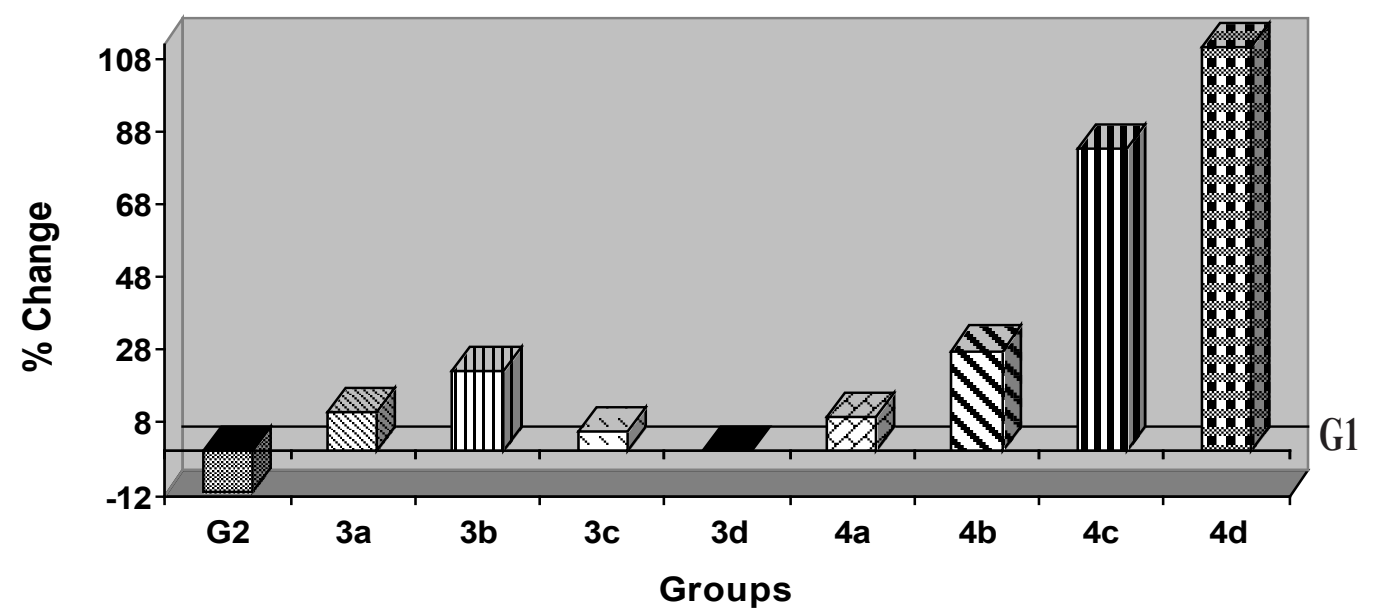

Fig. 4. Change percentage of granzyme B activity $(\mathrm{pg} / \mathrm{ml})$ of all studied groups. 


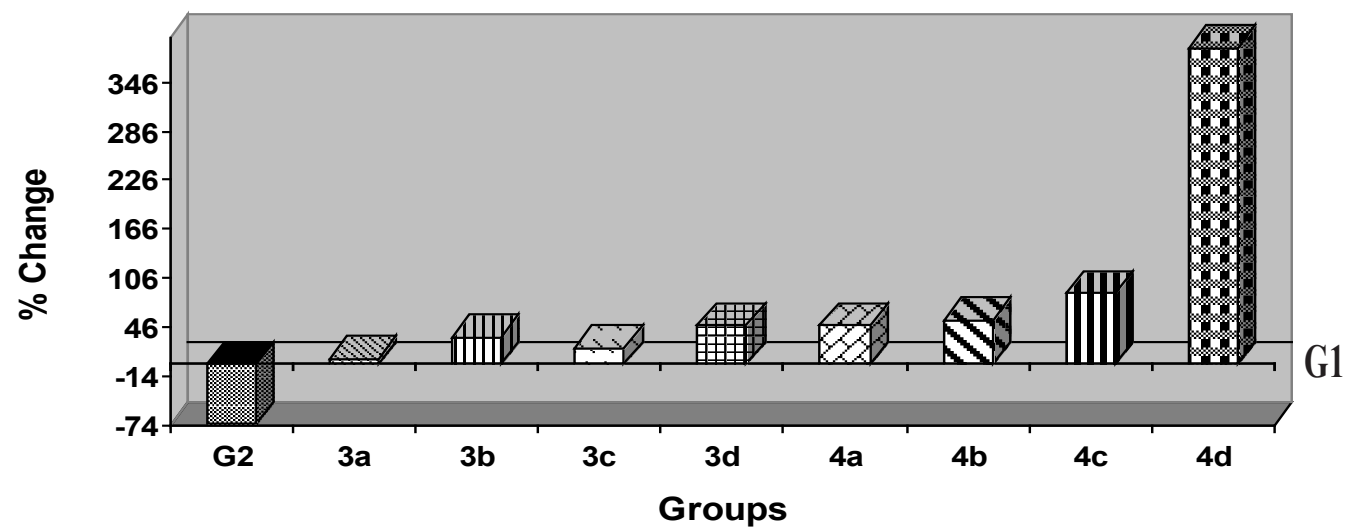

Fig. 5. Change percentage of caspase-3 activity $(\mathrm{ng} / \mathrm{ml})$ of all studied groups.

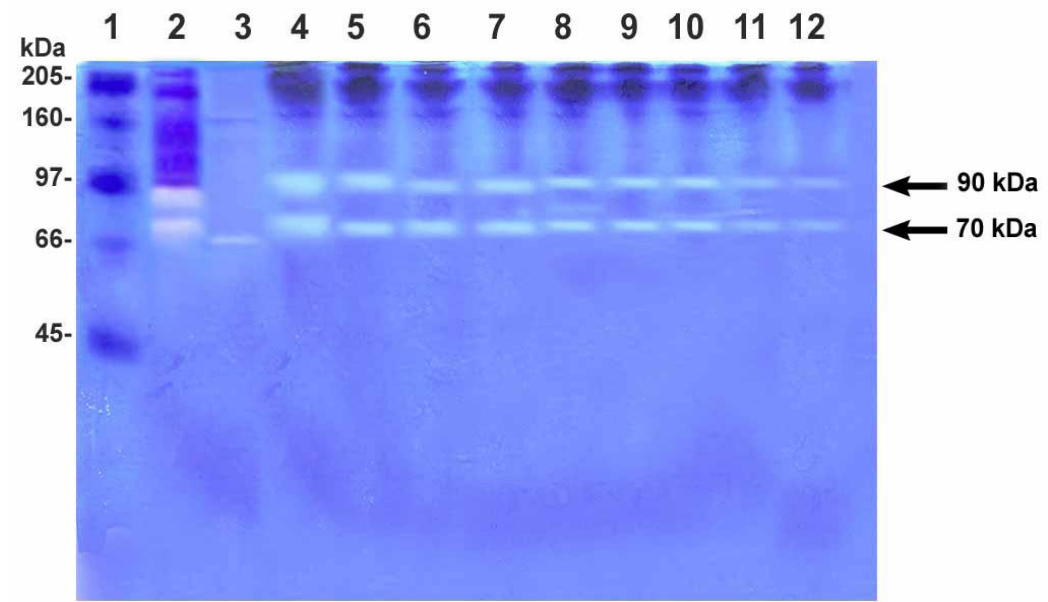

Fig. 6. Gelatin zymography for serum MMP-(2\&9) activity (70 \& 90KDa) of all studied groups.

Lane 1: Protein marker.

Lane 4: Serum G2.

Lane 7: Serum 3c subgroup.

Lane 10: Serum 4b subgroup.
Lane 2: Standard collagenase $(350 \mathrm{U} / \mathrm{mg})$.

Lane 5: Serum 3a subgroup.

Lane 8: Serum 3d subgroup.

Lane 11: Serum 4c subgroup.
Lane 3: Serum G1.

Lane 6: Serum 3b subgroup.

Lane 9: Serum 4a subgroup.

Lane 12: Serum 4d subgroup.

\section{Determination of serum protein fractionation}

Figure 7 presents the documented observations of the gel electrophoresis for protein fractionation in serum, Ehrlich ascites and placental protein extract and all the studied groups. In the two lanes (Ehrlich ascite protein [lane 2] and placental protein extract [lane 3]) similar bands were observed, the first band was detected at $7 \mathrm{kDa}$, suggesting that it is the Mig-7. A second band was observed between $29 \mathrm{kDa}-45 \mathrm{kDa}$, suggesting that it is for trophoblast-derived growth factor. A third band was detected $>67 \mathrm{kDa}$ suggesting it is for integrin and a fourth band was observed at $>116 \mathrm{kDa}$ suggesting that it is for the epidermal growth factor receptor (EGFR).

\section{Discussion}

The homology between neoplastic tissue and the developed placenta can be used to develop an approach for eliciting antitumor immunity (Zhong et al., 2006).

On this ground, the current study aims to investigate an antitumor xenogeneic placental extract sterilized using 0.2 micron Millipore filters (Centricon) or gamma irradiation. This extract was applied pre-tumor inoculation as a vaccine.

Initiation of immune responses towards selfproteins associated with tumor progression is a possible therapeutic approach to cancer. While administration of syngeneic or allogeneic proteins induces poor immune response, it was reported that administration of xenogeneic homologous proteins are able of eliciting immunity against the endogenous self-protein (Zhong et al., 2006). 


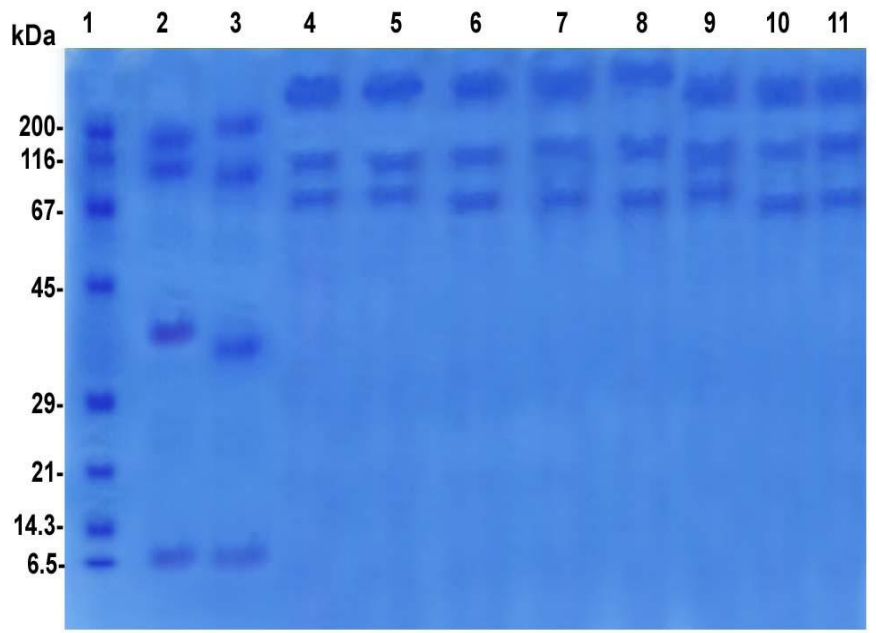

Fig.7. Gel electrophoresis for protein fractionation in serum, Ehrlich ascite and placental protein extract in all the studied groups.

Lane 1: SDS PAGE protein marker (6.5-200kDa). Lane 2: Sample of Ehrlich ascite protein.

Lane 3: placental protein extract.

Lane 6: Serum 3c subgroup.

Lane 9: Serum 4b subgroup.
Lane 4: Serum 3a subgroup.

Lane 7: Serum 3d subgroup.

Lane 10: Serum 4c subgroup.
Lane 5: Serum 3b subgroup. Lane 8: Serum 4a subgroup. Lane 11: Serum 4d subgroup.
Wagner et al. (2015) studied providing of placental, umbilical cord, and fetal derived endothelial cells for stimulation of an immune response in cancer patients. Results showed successful utilization of placental endothelial cells in induction of anticancer immunity regardless of tumor type. Liso et al. (2017) concluded that placenta specific 1 (PLAC1) antigens as a specific anti-cancer vaccine could induce anti-PLAC1 antibodies without causing infertility.

The parameters that were conducted in the present study may fulfill the objective of enhancement of the immune system as a defensive mechanism against tumor inoculation.

In this work, the placental extract was irradiated using a minimum dose of $2 \mathrm{~Gy}$ which is necessary for sterilization without causing placental protein degradation (Lee \& Hsu, 2004).

The obtained results clearly reflect the efficacy of the prepared xenogeneic placental extract vaccine in inhibition of tumor growth to a significant extent.

Lymphocytes are the major carriers of cellmediated immune mechanisms, and lymphocyte level is an index of cellular immune competence (Burnet, 1969). In the present study, the lymphocyte count showed significant increases in $3 \mathrm{~d}$, 4a, 4b, 4c and 4d subgroups compared to Ehrlich treated groups. $\mathrm{CD} 8^{+} \mathrm{T}$ lymphocytes are welldocumented effectors of tumor immunity. There is enough evidence on the prognostic significance of $\mathrm{CD} 8^{+}$lymphocytes within a tumor or in peripheral blood of cancer patients (Characiejus et al., 2011).

In the present study, $\mathrm{CD} 8^{+} \mathrm{T}$ lymphocytes activity in blood is an indicator of relapse of tumor and response to therapy. There is significant increases in CD8 $8^{+}$activity in $4 \mathrm{~b}$ and $4 \mathrm{~d}$ subgroups compared to Ehrlich treated group. On the other hand, $4 \mathrm{~d}$ subgroup showed a significant increase in $\mathrm{CD}^{+} \mathrm{T}$ lymphocytes activity compared to $\mathrm{G} 1$ group.

Effector CTL have the ability to promote the apoptotic death of carefully chosen target cells, using a combination of granule (perforin/ granzyme)- and receptor (Fas/tumour necrosis factor)-mediated mechanisms (Maher \& Davies, 2004).

Kanatani et al. (2011) found that delivery of the human pro-apoptotic enzyme GrB to tumor cells by yoked hCG has a significant selectivity and therapeutic potential for human tumors such as ovarian carcinomas.

In the present study, the granzyme B activity showed a significant increase in $4 \mathrm{~d}$ subgroup 
compared to G1 and G2 groups. Granzyme B cleaves its substrates after aspartic acid residues, so it is not astonishing that many caspases have been suggested to be direct granzyme B substrates including caspase- $3,-6,-7,-8,-9$ and -10 (Darmon et al., 1995).

Winter et al. (2001) recognized the significance of caspases in prostate cancer progression, they examined the expression of three key caspases, caspase-1, caspase-3, and caspase-9, in normal and malignant human prostates. This study suggests that the pattern of caspase- 1 and -3 expression in prostatic tumors may have prognostic significance in disease progression. In the present study, the caspase-3 activity showed significant increases in $4 \mathrm{c}$ and $4 \mathrm{~d}$ subgroups compared to $\mathrm{G} 1$ and $\mathrm{G} 2$ subgroups.

Juuti et al. (2007) indicated that the increased expression of MMP-2 is a sign of poor prognosis in cancer of the stomach and pancreas. TalvensaariMattila et al. (2005) investigated that high MMP9 levels in plasma or serum samples showed that MMP-9 expression may be associated with increased risk of recurrence and poor prognosis in prostate carcinoma.

In the present study, the gelatin zymography for serum MMP-(2\&9) activities $(70 \& 90 \mathrm{kDa})$ in all the studied groups demonstrated that MMP2 and MMP9 bands were detected in all the studied groups, but with less pronounced bands than that in Ehrlich treated group. 4d subgroup displays the least pronounced band compared to the other studied groups and to G2 group.

In the current study, gel electrophoresis for protein fractionation in Ehrlich, placental protein extract and serum protein of all the studied groups, revealed a band at $7 \mathrm{kDa}$, suggesting that it is the Mig-7, which is in agreement with Phillips \& Lindsey (2005) who found Mig-7 in circulating tumor cells and tumor tissue (regardless of tissue of origin) from more than 200 patients with cancer; notably, it was absent from healthy controls.

In the present study, a second band was detected between the $29 \mathrm{kDa}$ and $45 \mathrm{kDa}$ suggesting this band is for trophoblast-derived growth factor which is a peptide actively expressed in breast cancer and is one of the most abundant molecules present on trophoblast membranes as reported by Bishayee et al. (1984).
Much of the literature regarding cancer and integrins has implicated this family of adhesion receptors in tumour cell proliferation, migration and survival. The role of integrins in cell migration and invasion is one of their most studied functions in tumour biology. Integrins directly bind components of the extracellular matrix (ECM) and provide the traction necessary for cell motility and invasion (Desgrosellier \& Cheresh, 2010).

In the present study, a third band was detected $>67 \mathrm{kDa}$ suggesting that it is for integrin. This is in accordance with; Blechschmidt et al. (2007) who recorded that cellular program used by both cancer cells and trophoblast cells to promote invasion in epithelial-mesenchymal transition, which results in loss of cell-to-cell contact inhibition. Associated with this program there are changes in integrin expression and loss of E cadherin, allowing loss of polarity and enhanced motility.

Ferretti et al. (2006) reported that among growth factor receptors expressed by both normal trophoblasts and malignant nontrophoblastic tumours, there are those encoded by proto-oncogenes which, once activated, become oncogenes capable of inducing neoplasia. These receptors include epidermal growth factor receptor (EGFR).

In the present study, a fourth band was observed $>116 \mathrm{KDa}$ suggesting that it is for the epidermal growth factor receptor (EGFR).

For serum of all the studied groups, no bands for placental protein extract were detected, only bands for blood proteins (albumin, globulins and fibrinogen) were observed showing that the protein was captured as an antigen by DCs. This is in accordance with Palucka \& Banchereau (2012) who mentioned that antigen-loaded DCs migrate into the draining lymph nodes where they process the proteins into peptides that bind to both MHC class I molecules and MHC class II molecules, then antigen-loaded DCs can launch the differentiation of antigenspecific $\mathrm{T}$ cells into effector $\mathrm{T}$ cells with unique functions and cytokine profiles.

\begin{tabular}{ll} 
Listof abbreviations & \\
\hline $\begin{array}{l}\text { CD8+ } \\
\text { cells }\end{array}$ & Cytotoxic T cells \\
\hline
\end{tabular}




\begin{tabular}{lc}
\hline MMP & Matrix metalloproteinases \\
XPE & xenogeneic placental extract \\
CTLs & Cytotoxic T lymphocytes \\
NK & Natural killer \\
MTT & $\begin{array}{r}\text { 3-(4,5-dimethylthiazol-2-yl)-2,5- } \\
\text { diphenyltetrazolium bromide }\end{array}$ \\
\hline
\end{tabular}

\section{References}

Birkedal-Hansen, H. and Taylor, R.E. (1982) Detergent activation latent collagenase and resolution of its molecules. Biochem.Biophys. J. Res. Commun. 107, 1173-8.

Bishayee, S., Matesic, D. and Das, M. (1984) Identification of a 34,000-dalton mitogenic protein associated with plasma membranes from human A431 epidermoid carcinoma cells. J. Proc. Natl. Acad. Sci. USA, 81, 3399-3403.

Blechschmidt, K., Mylonas, I., Mayr, D., Schiessl, B., Schulze, S., Becker, K.F. and Jeschke, U (2007) Expression of E-cadherin and its repressor snail in placental tissue of normal, preeclamptic and HELLP pregnancies. J. Virchows Arch. 450(2), 195-202.

Burnet, M. (1969) "Cellular Immunology". Cambridge England: University Printing House, pp. 548-549.

Characiejus, D., Jacobs, J.J., Pašukonienè, V., Kazlauskaite, N., Danilevičiūtè, V. and Mauricas M. (2011) Prediction of response in cancer immunotherapy. J. Anticancer Res. 31, 639-647.

Cullen, S.P. and Martin, S.J. (2008) Review of mechanisms of granule-dependent killing. J. Cell Death Diff. 15, 251-262.

Darmon, A.J., Nicholson, D.W. and Bleackley, R.C. (1995) Activation of the apoptotic protease CPP32 by cytotoxic T-cell-derived granzyme B. J. Nature, 377, 446-448.

Desgrosellier, J.S. and Cheresh, D.A. (2010) Integrins in cancer: Biological implications and therapeutic opportunities. J. Nat. Rev. Cancer, 10(1), 9-22.

Ferretti, C., Bruni, L., Dangles-Marie, V., Pecking, A.P. and Bellet, D. (2006) Molecular circuits shared by placental and cancer cells, and their implications in the proliferative, invasive and migratory capacities of trophoblasts. J. Hum. Reprod. 13(2), 121-141.

Finn, O.J. (2003) Cancer vaccines: Between the idea and the reality. J. Nat. Rev. Immunol. 3(8), 630-641.

Hanahan, D. and Weinberg, R.A. (2000) The hallmarks of cancer. J. Cell, 100, 57-70.

Hanahan, D. and Weinberg, R. (2011) Hallmarks of cancer: The next generation. J. Cell, 144(5), 646-7410.

Harrell, C.R. (1991) Injectable soft tissue augmentation materials from the placenta and their method of manufacture. Patent Pub. No.: US 5,002, 071.

Holtan, S.G., Creedon, D.J., Haluska, P. and Markovic, S.N. (2009) Cancer and pregnancy: Parallels in growth, invasion, immune modulation and implication for cancer therapeutic agents. J. Mayo. Clin. Proc. 84(11), 985-1000.

Jemal, A., Bray, F., Center, M.M., Ferlay, J., Ward, E. and Forman, D. (2011) Global cancer statistics. $C A$ Cancer J Clin. 61(2), 69-90.

Juuti, A., Lundin, J., Nordling, S., Louhimo, J. and Haglund, C. (2007) Epithelial MMP-2 expression correlates with worse prognosis in pancreatic cancer. J. Oncology, 71(1-2), 61-68.

Kanatani, I., Lin, X., Yuan, X., Manorek, G., Shang, X., Cheung, L.H., Rosenblum, M.G. and Howell, S.B. (2011) Targeting granzyme B to tumor cells using a yoked human chorionic gonadotropin. J. Cancer Chemother. Pharmacol. 68, 979-990.

Karen, L., Devanarayan, V., Kriauciunas, A., Manetta, J., Montrose, C. and Sitta Sittampalam, S. (2014) Assay guidance manual [Internet]. Published by Eli Lilly \& Company and the National Center for Advancing Translational Sciences.

Kochenderfer, J.N. and Rosenberg, S.A. (2013) Treating B-cell cancer with $\mathrm{T}$ cells expressing antiCD19 chimeric antigen receptors. J. Nat. Rev. Clin. Oncol. 10(5), 267-276.

Lee, S.L. and Hsu, S.L. (2004) Placental preparation having antitumor activity. Patent Pub. No.: US 2004/0076618 A1.

Liso, A., Massenzio, F. and Stracci, F. (2017) PLAC1 
immunization does not induce infertility in mice. $J$ Immunotherapy, 9, 481-486.

Maher, J. and Davies, E.T. (2004) Targeting cytotoxic T lymphocytes for cancer immunotherapy. British $J$. of Cancer, 91, 817-821.

Nagle, D.G.; Zhou, Y.D., Mora, F.D., Mohammed, K.A. and Kim, Y.P. (2004) Mechanism targeted discovery of antitumor marine natural products. Curr. Med. Chem. 11(13), 1725-1756.

Palucka, K. and Banchereau, J. (2012) Cancer immunotherapy via dendritic cells. J. Nat. Rev. Cancer, 12, 265-277.

Phillips, T.M. and Lindsey, J.S. (2005) Carcinoma cell-specific Mig-7: A new potential marker for circulating and migrating cancer cells. $J$. Oncol. Rep. 13(1), 37-44.

Talvensaari-Mattila, A., Santala, M., Soini, Y. and Turpeen- niemi-Hujanen, T. (2005) Prognostic value of matrix metalloproteinase- 2 (MMP-2) expression in endometrial endometrioid adenocar- cinoma. $J$. Anticancer Research B., 25(6), 4101-4105.

Voron, T., Marcheteau, E., Pernot, S., Orianne, C., Tartour, E., Taieb, J. and Terme, M. (2014) Control of the immune response by pro-angiogenic factors. J. Front Oncol. 4, 70.

Wagner, P.D. and Srivastava, S. (2012) New paradigms in translational Science Research in cancer biomarkers. J. Transl. Res. 159(4), 343-353.
Wagner, S.C., Kim, A. J., Theofilopoulos, D.N., Dolan, B.R. and Ajili, N. (2015) Compositions and means for induction of tumor immunity. International Publication Number WO 2015/168503 A1.

Wilson, J.K., Sargent, J.M., Elgie, A.W., Hill, J.G. and Taylor, C.G. (1990) A feasibility for chemosensitivity testing in ovarian malignancy. $\mathrm{Br}$. J. Cancer, 62(2), 189-194.

Winter, R.N., Kramer, A., Borkowski, A. and Natasha Kyprianou (2001) Loss of caspase-1 and caspase-3 protein expression in human prostate cancer. $J$. Cancer Res. 61, 227-1232.

Wittig, I., Braun, H.P. and Schägger, H. (2006) Blue native PAGE. J. Nat. Protoc. 1(1), 418-428.

Xu, X., Wang, Y., Chen, Z., Sternlicht, M.D., Hidalgo, M. and Steffensen, B. (2005) Matrix metalloproteinase-2 contributes to cancer cell migration on collagen. J. Cancer Res. 65, 130-136.

Zhong, Z., Kusznieruk, K.P., Popov, I.A., Riordan, N.H., Izadi, H., Yijian, L., Sher, S., Szczurko, O. M., Agadjanyan, M.G., Tullis, R.H., Harandi, A., Reznik, B.N., Mamikonyan, G.V. and Ichim, T.E. (2006) Induction of antitumor immunity through xenoplacental immunization. J. Trans1. Med. 4, 22.

(Received 7 / 2 /2018; accepted $12 / 3 / 2018)$ 


$$
\begin{aligned}
& \text { إستهداف العلاج المناعي للسرطان من خلال التطعيم بالمستخلص المشيمي غير الأتي } \\
& \text { المشع } \\
& \text { سهير عبد العظيم عثمان, نادية محمد عبد الله*, فاطمة فرج عبد الحمياء*, محمد حسن نصر الدين***, اسماء }
\end{aligned}
$$

تهدف هذه الرسالة إلى تقدير مدي فاعلية العلاج بحقن بروتين المستخلص المشيمي غير الذاتي المعقم وذلك قبل

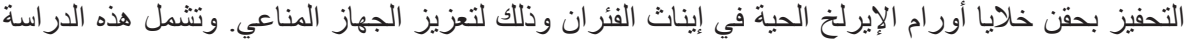

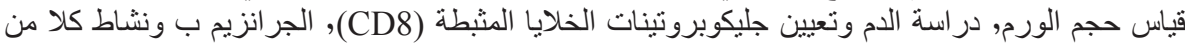

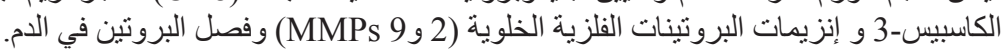

تم تقسيم إناث الفئر ان إلى المجموعة الأولي المجموعة الضابطة و المجموعة الثانية حقنت بخلايا أورام

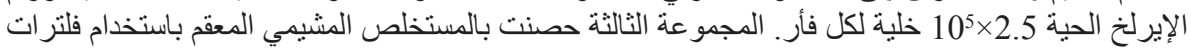

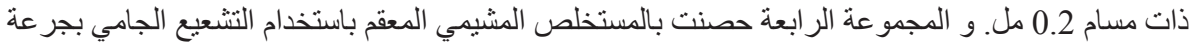

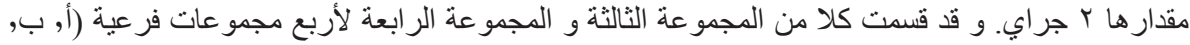

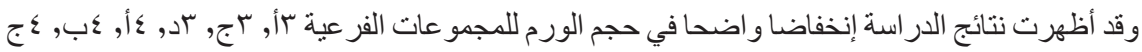

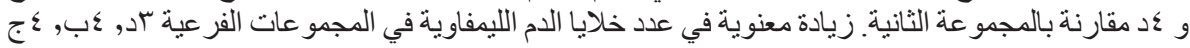

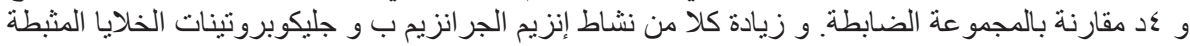

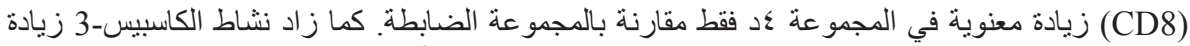

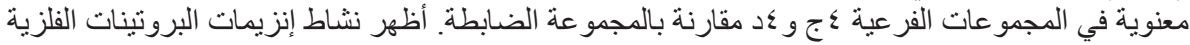

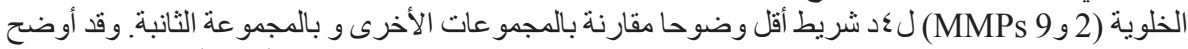

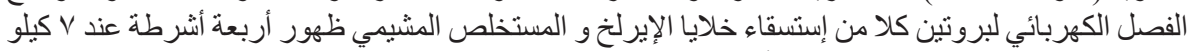

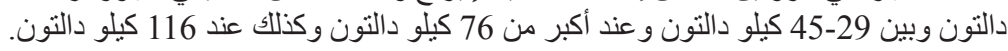
وقد أثتتت الدر اسة أن التطعيم بلقاح بروتين المستخلص المشيمي غير الذاتي أدى إلى تعزيز الجهاز المناعي. 